\title{
Konsumsi Pakan dan Indeks Pengurangan Sampah Buah dan Sayur Menggunakan Larva Black Soldier Fly
}

\section{Feed Consumption and Waste Reduction Index of Fruit and Vegetable Waste Using Black Soldier Fly Larva}

\author{
Nadiatuz Zahro, Novy Eurika*, Aulya Nanda Prafitasari \\ Pendidikan Biologi FKIP Universitas Muhammadiyah Jember \\ *eurika@unmuhjember.ac.id
}

diterima: 5 Januari 2021 ; dipublikasi: 31 Maret 2021

DOI: $10.32528 /$ bioma.v6i1.5034

\begin{abstract}
ABSTRAK
Tujuan dari penelitian ini adalah untuk mengetahui perbedaan biokonversi sampah buah dan sayur menggunakan larva BSF (Hermetia illucens). Penelitan ini merupakan penelitian eksperimen yang menggunakan Rancangan Acak Lengkap (RAL). Larva yang digunakan merupakan larva yang telah berumur 6 hari. Penelitan ini menggunakan 5 perlakuan perbandingan sampah buah dan sayur dengan perbandingan tertentu. Analisis data menggunakan uji kruskal wallis dan dilanjutkan dengan uji mann-whitneey dengan derajat kepercayaan $\alpha=0,05$. Hasil penelitian dan uji analisis data menunjukkan adanya perbedaan konsumsi pakan dan indeks pengurangan sampah pada perlakuan sampah buah dan sayur dengan perbandingan tertentu. Konsumsi pakan tertinggi terdapat pada perlakuan $80 \%$ sampah buah: $20 \%$ sampah sayur dengan nilai 2,202 gram/gram berat badan/hari. Perlakuan tersebut juga lebih banyak mereduksi sampah dengan nilai WRI 6,408 gram per hari.
\end{abstract}

Kata Kunci: Hermentia illucens, Biokonversi, WRI, Biomassa Larva BSF.

\section{ABSTRAC}

The aim of this study was to determine the difference in feed consumption and fruit and vegetable waste reduction index using BSF larvae (Hermetia illucens). This research is an experimental study using a completely randomized design (CRD). The larvae are 6 days old. This research uses 5 treatments of fruit and vegetable waste comparisons with a certain ratio. Data analysis used the Kruskal Wallis test and continued with the Mann-Whitney test with a degree of confidence $\alpha=0.05$. The results of the research and data analysis test showed that there were differences in feed consumption and waste reduction indexes in the treatment of fruit and vegetable waste with a certain ratio. The highest feed consumption was found in the treatment of $80 \%$ fruit waste: $20 \%$ vegetable waste with a value of 2.202 grams / gram body weight / day. This treatment also reduced waste more with a WRI value of 6.408 grams for a day.

Keywords: Hermetia illucens, Biokonversi, feed concumption, Biomass 


\section{PENDAHULUAN}

Sampah merupakan permasalahan lingkungan yang nyaris selalu dijumpai di setiap wilayah. Sampah semakin meningkat seiring dengan peningkatan jumlah dan aktivitas penduduk, tidak terkecuali di wilayah Kabupaten Lumajang, Jawa Timur. Jumlah timbunan di Kabupaten Lumajang tercatat sebanyak 91,25 ton/hari (Kementerian Lingkungan Hidup dan Kehutanan, 2018). Tingginya tingkat konsumsi masyarakat dapat menyebabkan semakin banyak sampah yang terdapat di lingkungan sekitar. Berdasarkan sumbernya, komposisi sampah terbanyak di Kabupaten Lumajang berasal dari sampah rumah tangga, yaitu mencapai 35\% dari total komposisi sampah yang ada (Sistem Informasi Pengelolaan Sampah Nasional, 2019). Sampah rumah tangga merupakan sampah yang berasal dari aktivitas rumah tangga sehari-hari. Sampah rumah tangga tidak termasuk tinja dan saampah spesifik.

Pada umumnya, sampah yang dihasilkan dalam rumah tangga meliputi sampah organik, anorganik dan sampah B3 (Bahan Beracun dan Berbahaya), dengan komposisi terbesar adalah sampah organik, yang mencapai 70\% (Widiarti, 2012). Sampah organik adalah jenis sampah yang mudah terurai secara alami (degradable). Sampah organik umumnya mudah membusuk dan berasal dari sisa makanan, kulit buah, sayuran, dan lain sebagainya. Meskipun sifat sampah organik mudah terurai secara alami, akan tetapi jumlahnya yang semakin meningkat menjadikan sampah organik sebagai permasalahan lingkungan yang serius saat ini. Sampah organik rumah tangga umumnya hanya dikumpulkan, diangkut lalu dibuang ke Tempat Pembuangan Akhir (TPA). Pengelolaan sampah dengan metode ini juga dibatasi oleh kapasitas tempat pembuangan maupun tenaga kerja pengangkut sampah. Akibatnya, banyak dijumpai timbunan sampah rumah tangga yang dibiarkan tidak terangkut dan terbuang selama berhari-hari sehingga menimbulkan permasalahan lingkungan, mulai dari persoalan estetika hingga kesehatan dan kenyamanan lingkungan.

Permasalahan pengeloaan sampah sebagaimana uraian diatas juga terjadi di Kecamatan Yosowilangun, Kabupaten Lumajang, Jawa Timur. Kecamatan dengan jumlah rumah tangga mencapai 16.348 (Enviromental Health Risk Assesment (EHRA), 2016), juga mengalami permasalahan terkait pengelolaan sampah rumah tangga. Pengeloaan sampah rumah tangga di kecamatan Yosowilangun dilakukan dengan pembakaran, dikumpulkan di TPS, dibuang ke lubang lalu ditutup, dibuang ke lubang 
tanpa ditutup, dibuang ke laut/sungai, dan dibuang ke lahan kosong hingga membusuk (Enviromental Health Risk Assesment (EHRA), 2016). Menurut Rahmadani dan Padang (2017) pengelolaan sampah tidak dapat diselesaikan hanya oleh pemerintah daerah dengan kumpul-angkut-buang ke TPA saja, tetapi harus dilakukan secara komprehensif dan terpadu dari hulu ke hilir agar memberikan manfaat secara ekonomi. Salah satu metode pengelolaan sampah, khususnya sampah organik yang dapat memberikan manfaat secara ekonomi adalah biokonversi.

Konsep biokonversi mengacu pada penggunaan organisme untuk mengubah limbah organik menjadi biomassa dan bahan organik sederhana. Salah satu agen biokonvesi adalah larva black soldier fly (Hermetia illucens) (Manurung et al., 2016). Pemanfaatan black soldier fly (Hermetia illucens) untuk mengelola sampah organik diperkenalkan pada tahun 1990-an, dan semakin mendapat perhatian hingga saat ini (Rahmi et al., 2020). Berbagai penelitian telah menunjukkan kemampuan larva BSF untuk mengkonversi sampah organik menjadi biomassa dengan kandungan protein dan asam lemak tertentu yang dapat digunakan sebagai pengganti tepung ikan dan pakan ternak maupun biofuel bioetanol (Manurung et al., 2016).

Hermetia illucens merupakan salah satu spesies dari ordo Diptera dan Famili Stratiomyidae. Spesies ini berasal dari Amerika, dan kemudian menyebar luas terutama di kawasan tropis dan subtropis (Wang \& Shelomi, 2017). Tahap perkembangan $H$. illucens terdiri dari telur, larva, pupa, dan dewasa. Di alam, lalat BSF bertelur di daerah kering dekat organisme basah dan membusuk. Suhu, kelembaban, dan intensitas cahaya merupakan faktor lingkungan utama yang mempengaruhi reproduksi. Waktu inkubasi telur biasanya 4-14 hari dan bervariasi dengan musim, wilayah, dan suhu. Fase larva terdiri dari enam instar, dan ukuran larva berkisar antara $1,8 \mathrm{~mm}$ sampai $20 \mathrm{~mm}$, dengan larva $20 \mathrm{~mm}$ disebut sebagai larva dewasa. Larva BSF mulai makan segera setelah menetas, dengan konsumsi yang meningkat pesat setelah instar ke-3. Ketika mencapai instar ke-6, larva akan mereka berhenti makan dan memulai fase pupa, dan kemudian menjadi dewasa. Lalat betina dewasa mulai bertelur kira-kira 2-3 hari setelah kawin, dan fekunditas betina bisa mencapai 900 telur / betina. Performa dan nutrisi larrva BSF bervariasi menurut substrat, dimana substrat yang kaya protein dan lemak lebih kondusif untuk akumulasi protein dan lemak pada serangga ini (Liu et al., 2019). 
Larva BSF mampu aktif menguraikan makanan dalam waktu 21-24 hari sesuai dengan suhu lingkungan. Suhu lingkungan yang rendah akan memperlama proses penguraian lingkungan (Fahmi, 2018). Penelitian lain menyebutkan bahwa larva BSF mampu menguraikan sampah rumah tangga sebanyak 8122,1 gram, sampah melon sebanyak 1859,7 gram, sampah sawi putih sebanyak 1320,3 gram, dan ampas tahu sebanyak 1683,3 gram (Salman, 2020).

Efisiensi degradasi sampah organik yang dapat terurai ini oleh larva BSF dilaporkan berkisar antara 55 hingga 80\% (Beesigamukama et al., 2021). Proses biokonversi menggunakan larva BSF dipengaruhi oleh jenis, kuantitas dan kualitas pakan dan faktor lingkungan yang beragam. Kombinasi yang tepat dari parameterparameter ini dapat meningkatkan efisiensi biokonversi dalam hal pengurangan komposit yang tidak diinginkan, stabilisasi bahan organik, produksi biomassa yang optimal, waktu biokonversi, dan lain-lain (Parra Paz et al., 2015).

Komposisi unsur hara yang terdapat pada limbah juga berpengaruh pada kinerja larva dalam menguraikan sampah. Secara khusus, mencampur beberapa jenis sampah dapat memberikan pakan yang lebih bergizi dan seimbang untuk pertumbuhan larva (Gold et al., 2020). Di dalam sampah rumah tangga, sampah buah dan sayur juga merupakan jenis sampah yang paling banyak dijumpai, selain sampah sisa makanan. Menurut Cammack dan Tomberlin (2017) campuran sampah buah dan sayur pada umumnya mengandung sekitar $20 \%$ protein, 2\% lemak, and 69\% karbohidrat. Kandungan nutrisi pada pakan akan mempengaruhi pertumbuhan serta performa larva BSF dalam mengkonversi sampah.

Larva BSF menguraikan sampah organik dengan cepat. Larva BSF diharapkan mampu mengurai jumlah dan bau tidak sedap pada sampah buah dan sayur. Hasil biokonversi sampah buah dan sayur juga diharapkan dimanfaatkan menjadi kompos guna memenuhi pangan kaya gizi untuk kebutuhan keluarga. Namun, belum diketahui berapa banyak sampah organik campuran buah dan sayur yang dapat dikonversi oleh larva BSF. Penelitian ini bertujuan untuk mengetahui perbedaan biokonversi sampah buah dan sayur menggunakan larva BSF (Hermetia illucens). Penelitian ini dimaksudkan untuk mengetahui konsumsi pakan dan indeks pengurangan sampah buah dan sayur menggunakan larva BSF (Hermetia illucens). 


\section{METODE}

\section{Alat Penelitian}

Penelitian ini menggunakan peralatan alat sederhana sebagai tempat perlakuan biokonversi sampah dengan larva BSF sebagaimana tampak pada Gambar 1. Alat ini berupa rak platik dengan lima tingkatan, dan pada masing masing tingkatan terdapat 5 buah wadah plastik dengan volume $1000 \mathrm{~mL}$ sebagai tempat perlakuan sampah dan larva BSF. Peralatan lain yang juga digunakan adalah timbangan analitik, pinset, kasa penutup, dan ember untuk pemeliharaan dan kultivasi larva BSF.

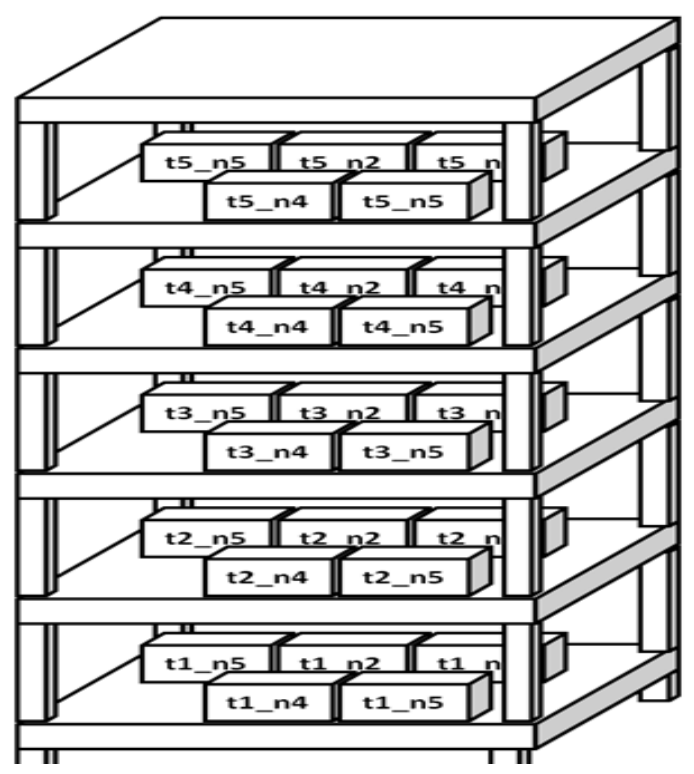

Gambar 1: Rak Perlakuan Biokonversi Sampah dengan Larva BSF

\section{Bahan Penelitian}

Bahan-bahan yang digunakan dalam penelitian ini adalah antara lain larva Hermetia illucens (Diptera: Stratiomyidae) (BSF). Larva diperoleh dari produksi telur serangga Hermetia illucens hasil produksi di Omah Magot Lumajang, Jawa Timur. Jumlah larva BSF yang diaplikasikan dalam tiap wadah sebanyak 200 ekor. Selain larva BSF, bahan lain yang digunakan dalam penelitian ini adalah campuran sampah buah dan sayur. Sampah buah pada penelitian ini meliputi kulit semangka, kulit pisang, pepaya busuk, dan kulit melon sedangkan jenis sampah sayur yang digunakan adalah kangkung, bayam, sawi, dan kol. Jenis sampah buah dan sayur yang digunakan dalam penelitian ini berdasarkan hasil observasi jenis sampah buah dan sayur yang terdapat pada sampah rumah tangga warga RT 05 RW 003 Desa Yosowilangun Kidul, 
Kecamatan Yosowilangun, Kabupaten Lumajang. Jumlah sampah yang dibutukan untuk setiap wadah perlakukan adalah sebanyak 300 gr campuran sampah buah dan sayur.

\section{Prosedur Penelitian}

Penelitian diawali dengan tahap persiapan media untuk penetasan telur lalat BSF, yaitu berupa campuran dedak, pelet ikan, dan nasi sisa sebagai nutrisi larva. Dalam wadah penetasan ini juga menggunakan daun pisang sebagai alas/media peletakan telur lalat. Telur lalat BSF yang telah diperoleh selanjutnya diinkubasi terlebih selama \pm 3 hari agar menetas. Telur yang telah menetas menjadi larva kemudian dikultivasi selama 6 hari. Larva berumur 6 hari selanjutnya digunakan sebagai agen biokonversi sampah buah dan sayur. Media yang berfungsi sebagai umpan atau pakan untuk larva BSF adalah berupa campuran sampah buah dan sayur, yang terdiri dari sampah kulit semangka, kulit pisang, pepaya busuk, kangkung, bayam, sawi, dan kol. Media umpan yang digunakan dalam penelitian ini terdiri atas 5 kombinasi perlakuan perbandingan sampah buah dan sayur. Variasi perlakuan perbandingan sampah buah dan sayur pada media pakan yang digunakan dalam penelitian ini disajikan pada Tabel 1.

Tabel 1. Kode dan Keterangan Perlakuan pada Penelitian

\begin{tabular}{lcc}
\hline No & Kode Perlakuan & Keterangan \\
\hline 1. & T1 & 20\% sampah buah : 80\% sampah sayur \\
\hline 2. & T2 & 35\% sampah buah : 65\% sampah sayur \\
\hline 3. & T3 & 50\% sampah buah : 50\% sampah sayur \\
\hline 4. & T4 & 65\% sampah buah : 35\% sampah sayur \\
\hline 5. & T5 & 80\% sampah buah : 20\% sampah sayur \\
\hline
\end{tabular}

Biokonversi dilakukan dengan memberikan umpan/pakan pada larva BSF sesuai dengan variasi perlakuan sebanyak $100 \mathrm{mg} / \mathrm{larva} / \mathrm{hari}$ selama 15 hari masa pemeliharaan. Pada masing masing perlakuan dilakukan sebanyak 5 kali pengulangan. Parameter yang diamati meliputi komsumsi pakan (feed consumption) dan indeks pengurangan sampah (waste reduction index). Konsumsi pakan (feed consumption) adalah banyaknya pakan yang terkonsumsi oleh larva BSF selama masa pemeliharaan. Konsumsi pakan didapatkan dengan mengurangkan masaa pakan awal dan massa pakan akhir dibagi dengan massa pakan awal (Hakim, 2017). Konsumsi larva dinyatakan dalam persen. Konsumsi pakan dapat dihitung dengan rumus berikut:

$\mathrm{KP}=\frac{\text { Massa pakan awal-massa pakan akhir }}{\text { massa pakan awal }} \times 100 \%$ 
Indeks pengurangan sampah (waste reduction index) menunjukkan tingkat pengurangan sampah pada periode pemberian pakan. Nilai WRI yang tinggi

$\mathrm{WRI}=\frac{D}{t} \mathrm{x} 100$

$\mathrm{D}=\frac{W-R}{W}$

Keterangan:

W : jumlah pakan total $(\mathrm{g})$

t : total waktu larva memakan pakan (hari)

$\mathrm{R} \quad$ : sisa umpan total setelah waktu tertentu $(\mathrm{g})$

D : penurunan umpan total

WRI : waste reduction indeks (indeks pengurangan sampah)

Data kemudian dianalisis menggunakan SPSS versi 25 dengan menggunakan uji kruskal wallis dengan kepercayaan 95\%, kemudian dilanjutkan dengan uji lanjutan Mann whitney.

\section{HASIL DAN PEMBAHASAN}

\section{Konsumsi Pakan Larva BSF}

Nilai konsumsi pakan menunjukkan banyaknya jumlah sampah buah dan sayur yang dikonsumsi oleh lava black soldier fly. Pengukuran konsumsi pakan dilakukan diakhir pemeliharaan, yaitu pada hari ke 15. Hasil konsumsi pakan dinyatakan dalam persen. Tabel 2 menunjukkan bahwa rata-rata konsumsi pakan yang dihasilkan dari pemberian pakan campuran sampah buah dan sayur dengan berbagai variasi perbandingan berkisar antara 91,08\%-96,23\%.

Tabel 2. Nilai Rata-Rata Konsumsi Pakan Sampah Buah dan Sayur Larva BSF

\begin{tabular}{lll}
\hline Kode Perlakuan & \multicolumn{1}{c}{ Komposisi Sampah Buah : Sayur } & \multicolumn{1}{c}{$\begin{array}{c}\text { Rata rata } \\
\text { Konsumsi pakan (\%) }\end{array}$} \\
\hline T1 & 20\% sampah buah : 80\% sampah sayur & 95,37 \\
\hline T2 & 35\% sampah buah : 65\% sampah sayur & 94,506 \\
\hline T3 & 50\% sampah buah : 50\% sampah sayur & 94,736 \\
\hline T4 & 65\% sampah buah : 35\% sampah sayur & 95,486 \\
\hline T5 & 80\% sampah buah : 20\% sampah sayur & 96,24 \\
\hline
\end{tabular}

Berdasarkan Tabel 2 di atas, konsumsi pakan tertinggi pada penelitian ini terdapat pada perlakuan T5 (80\% sampah buah : 20\% sampah sayur) yaitu sebesar 96,24\%, sedangkan terndah terdapat pada perlakuan T2 (35\% sampah buah : 65\% sampah sayur) sebesar 94,51\%. Tingginya konsumsi pakan pada perlakuan T5 
dikarenakan perbandingan sampah buah lebih banyak dibandingkan dengan sampah sayur.

Kadar air dalam buah buahan lebih banyak daripada sayuran. Kadar air pada semangka sebesar 90,7\% kulit pisang 69,8\%, kulit melon 83,50\%, dan pepaya sebesar 80,84\% (Pusat Penelitian dan Pengembangan Permukiman, 2015). Kadar air yang cukup tinggi pada buah dapat meyebabkan pakan menjadi lunak sehingga mudah dicerna larva. Larva black soldier fly dapat mereduksi sampah dengan baik pada sampah berbentuk slurry (Supriyatna, 2017). Kebutuhan akan kadar air makanan yang tinggi dapat dikaitkan dengan morfologi bagian mulut larva BSF, yang menyerupai karakteristik serangga pemulung. Tipe alat mulut ini memungkinkan larva BSF untuk mengikis makanan dari permukaan makanan. Dengan melembutkan padatan pakan, peningkatan kadar air makanan memudahkan larva untuk makan. Larva BSF juga mampu secara efisien mengonversi limbah dan produk sampingan dengan kandungan serat yang tinggi, berkat kehadiran bakteri usus di saluran pencernaan yang mampu mendegradasi selulosa (Meneguz et al., 2018)

Nilai konsumsi pakan pada penelitian ini lebih tinggi daripada penelitian sebelumnya. Penelitian Muhayyat (2016) yang menggunakan limbah domestik sebagai pakan mendapatkan hasil konsumsi umpan tertinggi terdapat pada daun singkong dengan nilai 69,49\%. Penelitian lainnya menggunakan umpan jeroan ikan dan dan kepala ikan mendapatkan hasil konsumsi pakan tertinggi pada kepala ikan dengan nilai 77,09\% (Hakim, 2017).

Hasil uji kruskal wallis pada pada variabel konsumsi pakan menunjukkan bahwa nilai signifikasi perlakuan pada konsumsi pakan sebesar 0,037 lebih kecil dari alfa $(\alpha=0,05)$ sehingga disimpulkan bahwa terdapat perbedaan konsumsi pakan pada pemberian pakan sampah buah dan sayur dengan perbandingan komposisi tertentu. Hasil uji kruskal wallis pada konsumsi pakan disajikan pada Tabel 3.

Tabel 3. Hasil Uji Kruskal Wallis Konsumsi Pakan Larva BSF pada

Sampah Buah dan Sayur

\begin{tabular}{ll} 
Test Statistics $^{\text {a,b }}$ & nilai \\
\hline Kruskal-Wallis H & 10,219 \\
\hline df & 4 \\
\hline Asymp. Sig. &, 037 \\
\hline a. Kruskal Wallis Test & \\
b. Grouping Variable: perlakuan
\end{tabular}


Berdasarkan hasil uji kruskal wallis, selanjutnya dilakukan uji lanjut MannWhitney pada variabel konsumsi pakan sebagaimana tampak pada Tabel 4.

Tabel 4. Hasil Uji Mann-Whitney pada Konsumsi Pakan

\begin{tabular}{|c|c|c|}
\hline \multicolumn{2}{|l|}{ Perbandingan perlakuan } & Nilai \\
\hline \multirow[t]{5}{*}{ Perlakuan T1: Perlakuan T2 } & Mann-Whitney U & 7,000 \\
\hline & Wilcoxon W & 22,000 \\
\hline & $\mathrm{Z}$ & $-1,149$ \\
\hline & Asymp. Sig. (2-tailed) & ,251 \\
\hline & Exact Sig. [2*(1-tailed Sig.)] &, $310^{b}$ \\
\hline \multirow[t]{5}{*}{ Perlakuan T1: Perlakuan T3 } & Mann-Whitney U & 12,000 \\
\hline & Wilcoxon W & 27,000 \\
\hline & $\mathrm{Z}$ &,- 104 \\
\hline & Asymp. Sig. (2-tailed) & 917 \\
\hline & Exact Sig. [2*(1-tailed Sig.)] & $1,000^{\mathrm{b}}$ \\
\hline \multirow[t]{5}{*}{ Perlakuan T1: Perlakuan T4 } & Mann-Whitney U & 9,000 \\
\hline & Wilcoxon W & 24,000 \\
\hline & $\mathrm{Z}$ &,- 731 \\
\hline & Asymp. Sig. (2-tailed) & ,465 \\
\hline & Exact Sig. [2*(1-tailed Sig.)] &, $548^{b}$ \\
\hline \multirow[t]{5}{*}{ Perlakuan T1: Perlakuan T5 } & Mann-Whitney U &, 000 \\
\hline & Wilcoxon W & 15,000 \\
\hline & $\mathrm{Z}$ & $-2,611$ \\
\hline & Asymp. Sig. (2-tailed) & ,009 \\
\hline & Exact Sig. [2*(1-tailed Sig.)] &, $008^{b}$ \\
\hline \multirow[t]{5}{*}{ Perlakuan T2: Perlakuan T3 } & Mann-Whitney U & 12,000 \\
\hline & Wilcoxon W & 27,000 \\
\hline & $\mathrm{Z}$ &,- 104 \\
\hline & Asymp. Sig. (2-tailed) & 917 \\
\hline & Exact Sig. [2*(1-tailed Sig.)] & $1,000^{\mathrm{b}}$ \\
\hline \multirow[t]{5}{*}{ Perlakuan T2: Perlakuan T4 } & Mann-Whitney U & 6,000 \\
\hline & Wilcoxon W & 21,000 \\
\hline & $\mathrm{Z}$ & $-1,358$ \\
\hline & Asymp. Sig. (2-tailed) &, 175 \\
\hline & Exact Sig. [2*(1-tailed Sig.)] &, $222^{b}$ \\
\hline \multirow[t]{5}{*}{ Perlakuan T2: Perlakuan T5 } & Mann-Whitney U & 3,000 \\
\hline & Wilcoxon W & 18,000 \\
\hline & $\mathrm{Z}$ & $-1,984$ \\
\hline & Asymp. Sig. (2-tailed) & ,047 \\
\hline & Exact Sig. [2*(1-tailed Sig.)] &, $056^{\mathrm{b}}$ \\
\hline \multirow[t]{5}{*}{ Perlakuan T3: Perlakuan T4 } & Mann-Whitney U & 11,000 \\
\hline & Wilcoxon W & 26,000 \\
\hline & $\mathrm{Z}$ &,- 313 \\
\hline & Asymp. Sig. (2-tailed) &, 754 \\
\hline & Exact Sig. [2*(1-tailed Sig.)] &, $841^{b}$ \\
\hline \multirow[t]{5}{*}{ Perlakuan T3: Perlakuan T5 } & Mann-Whitney U & 1,500 \\
\hline & Wilcoxon W & 16,500 \\
\hline & $\mathrm{Z}$ & $-2,305$ \\
\hline & Asymp. Sig. (2-tailed) & ,021 \\
\hline & Exact Sig. [2*(1-tailed Sig.)] &, $016^{\mathrm{b}}$ \\
\hline \multirow[t]{5}{*}{ Perlakuan T4: Perlakuan T5 } & Mann-Whitney U &, 500 \\
\hline & Wilcoxon W & 15,500 \\
\hline & $\mathrm{Z}$ & $-2,514$ \\
\hline & Asymp. Sig. (2-tailed) & ,012 \\
\hline & Exact Sig. [2*(1-tailed Sig.)] &, $008^{b}$ \\
\hline
\end{tabular}


Hasil uji Mann-Whitney pada Tabel 4 menyatakan nlai signifikasi antara perbandingan perlakuan T1: perlakuan T5, perlakuan T2: perlakuan T5, perlakuan T3: perlakuan T5, dan perlakuan T4: perlakuan T5 kurang dari alpha $(\alpha=0,05)$ sehingga terdapat perbedaan yang signifikan.

\section{Indeks Pengurangan Sampah}

Indeks pengurangan sampah menunjukkan tingkat pengurangan sampah selama 15 hari. Nilai indeks pengurangan sampah tertinggi terdapat pada kelompok perlakuan T5 (80\% sampah buah : 20\% sampah sayur) dengan nilai rata rata 6,408gr/hari, sedangkan terendah terdapat pada perlakuan T2 (35\% sampah buah : 65\% sampah sayur) dengan rata rata 6,248 gr/hari. Gambaran rata-rata indeks pengurangan sampah buah dan sayur oleh larva BSF disajikan pada Tabel 5.

Tabel 5. Nilai rata-rata Indeks Pengurangan Sampah Buah dan Sayur oleh Larva BSF

\begin{tabular}{lllll}
\hline Perlakuan & $\begin{array}{c}\text { Total } \\
\text { Pakan }\end{array}$ & Sisa Pakan Total & $\begin{array}{c}\text { Konsumsi Pakan (g/g } \\
\text { berat badan/hari) }\end{array}$ & $\begin{array}{c}\text { Indeks } \\
\text { Pengurangan } \\
\text { Sampah (g/hari) }\end{array}$ \\
\hline T1 & 300 & 13,84 & 1,41 & 6,352 \\
\hline T2 & 300 & 16,47 & 1,324 & 6,248 \\
\hline T3 & 300 & 15,78 & 1,838 & 6,304 \\
\hline T4 & 300 & 13,54 & 1,866 & 6,354 \\
\hline T5 & 300 & 11,27 & 2,302 & 6,408 \\
\hline
\end{tabular}

Keterangan:

T1 : 20\% sampah buah : $80 \%$ sampah sayur

T2 : $35 \%$ sampah buah : $65 \%$ sampah sayur

T3 : $50 \%$ sampah buah : $50 \%$ sampah sayur

T4 : $25 \%$ sampah buah : $35 \%$ sampah sayur

T5 : $80 \%$ sampah buah : $20 \%$ sampah sayur

Nilai indeks pengurangan sampah yang tinggi menunjukkan bahwa kemampuan larva dalam mereduksi sampah juga tinggi. Menurut (Hakim, 2017) nilai indeks pengurangan sampah berbanding lurus dengan konsumsi pakan. Pada Tabel 5 dapat dilihat bahwa urutan nilai konsumsi pakan dan indeks pengurangan sampah pada penelitian ini sama, sehingga dapat disimpulkan bahwa nilai konsumsi pakan berbanding lurus dengan nilai indeks pengurangan sampah. Sampah dengan total pakan $100 \mathrm{mg} / \mathrm{larva} / \mathrm{hari}$ sangat sesuai digunakan dalam mengurangi sampah secara efisien selama 15 hari dengan jumlah larva 200 ekor. Semakin tinggi nilai WRI maka sampah rumah tangga yang berkurang semakin banyak sehingga lingkungan semakin bersih.

Hasil uji kruskal wallis pada variabel indeks pengurangan sampah menunjukkan bahwa nilai signifikasi perlakuan pada indeks pengurangan sampah 
sebesar 0,037 lebih kecil dari alfa $(\alpha=0,05)$ sehingga disimpulkan bahwa terdapat perbedaan indeks pengurangan sampah pada pemberian pakan sampah buah dan sayur dengan perbandingan komposisi tertentu. Hasil uji kruskal wallis variabel indeks pengurangan sampah disajikan pada Tabel 6.

\section{Tabel 6. Hasil Hasil Uji Kruskal Wallis pada Indeks Pengurangan Sampah}

\section{Test Statistics ${ }^{\text {a,b }}$}

\begin{tabular}{ll} 
& nilai \\
\hline Kruskal-Wallis H & 10,219 \\
\hline df & 4 \\
\hline Asymp. Sig. &, 037 \\
\hline
\end{tabular}

a. Kruskal Wallis Test

b. Grouping Variable: perlakuan

Berdasarkan hasil uji kruskal wallis, selanjutnya dilakukan uji lanjut MannWhitney pada variabel indeks pengurangan sampah sebagaimana tampak pada Tabel 7.

\section{Tabel 7. Hasil Hasil Uji Mann-Whitney pada Indeks Pengurangan Sampah}

\begin{tabular}{|c|c|c|}
\hline Perbandingan perlakuan & & Nilai \\
\hline \multirow[t]{5}{*}{ Perlakuan T1: Perlakuan T2 } & Mann-Whitney U & 7,000 \\
\hline & Wilcoxon W & 22,000 \\
\hline & $\mathrm{Z}$ & $-1,149$ \\
\hline & Asymp. Sig. (2-tailed) & ,251 \\
\hline & Exact Sig. [2*(1-tailed Sig.)] &, $310^{\mathrm{b}}$ \\
\hline \multirow[t]{5}{*}{ Perlakuan T1: Perlakuan T3 } & Mann-Whitney U & 12,000 \\
\hline & Wilcoxon W & 27,000 \\
\hline & $\mathrm{Z}$ &,- 104 \\
\hline & Asymp. Sig. (2-tailed) & ,917 \\
\hline & Exact Sig. [2*(1-tailed Sig.)] & $1,000^{b}$ \\
\hline \multirow[t]{5}{*}{ Perlakuan T1: Perlakuan T4 } & Mann-Whitney U & 9,000 \\
\hline & Wilcoxon W & 24,000 \\
\hline & $\mathrm{Z}$ &,- 731 \\
\hline & Asymp. Sig. (2-tailed) & 465 \\
\hline & Exact Sig. [2*(1-tailed Sig.)] &, $548^{b}$ \\
\hline \multirow[t]{5}{*}{ Perlakuan T1: Perlakuan T5 } & Mann-Whitney U &, 000 \\
\hline & Wilcoxon W & 15,000 \\
\hline & $\mathrm{Z}$ & $-2,611$ \\
\hline & Asymp. Sig. (2-tailed) &, 009 \\
\hline & Exact Sig. [2*(1-tailed Sig.)] &, $008^{\mathrm{b}}$ \\
\hline \multirow[t]{5}{*}{ Perlakuan T2: Perlakuan T3 } & Mann-Whitney U & 12,000 \\
\hline & Wilcoxon W & 27,000 \\
\hline & $\mathrm{Z}$ &,- 104 \\
\hline & Asymp. Sig. (2-tailed) & 917 \\
\hline & Exact Sig. [2*(1-tailed Sig.)] & $1,000^{b}$ \\
\hline \multirow[t]{5}{*}{ Perlakuan T2: Perlakuan T4 } & Mann-Whitney U & 6,000 \\
\hline & Wilcoxon W & 21,000 \\
\hline & $\mathrm{Z}$ & $-1,358$ \\
\hline & Asymp. Sig. (2-tailed) &, 175 \\
\hline & Exact Sig. [2*(1-tailed Sig.)] &, $222^{\mathrm{b}}$ \\
\hline \multirow[t]{3}{*}{ Perlakuan T2: Perlakuan T5 } & Mann-Whitney U & 3,000 \\
\hline & Wilcoxon W & 18,000 \\
\hline & $\mathrm{Z}$ & $-1,984$ \\
\hline
\end{tabular}




\begin{tabular}{lll}
\hline & \multicolumn{1}{l}{ Asymp. Sig. (2-tailed) } &, 047 \\
\cline { 2 - 3 } & Exact Sig. [2*(1-tailed Sig.)] &, $056^{\mathrm{b}}$ \\
\hline Perlakuan T3: Perlakuan T4 & Mann-Whitney U & 11,000 \\
\cline { 2 - 3 } & Wilcoxon W & 26,000 \\
\cline { 2 - 3 } & $\mathrm{Z}$ &,- 313 \\
\cline { 2 - 3 } & Asymp. Sig. (2-tailed) &, 754 \\
\cline { 2 - 3 } & Exact Sig. [2*(1-tailed Sig.)] &, $841^{\mathrm{b}}$ \\
\hline Perlakuan T3: Perlakuan T5 & Mann-Whitney U & 1,500 \\
\cline { 2 - 3 } & Wilcoxon W & 16,500 \\
\cline { 2 - 3 } & Z & $-2,305$ \\
\cline { 2 - 3 } & Asymp. Sig. (2-tailed) &, 021 \\
\cline { 2 - 3 } & Exact Sig. [2*(1-tailed Sig.)] &, $016^{\mathrm{b}}$ \\
\hline Perlakuan 4: Perlakuan 5 & Mann-Whitney U &, 500 \\
\cline { 2 - 3 } & Wilcoxon W & $-2,514$ \\
\cline { 2 - 3 } & Z &, 012 \\
\cline { 2 - 3 } & Asymp. Sig. (2-tailed) &, $008^{\mathrm{b}}$ \\
\cline { 2 - 3 } & Exact Sig. [2*(1-tailed Sig.)] & 1500 \\
\hline
\end{tabular}

Hasil uji Mann-Whitney pada Tabel 7 menyatakan nlai signifikasi antara perbandingan perlakuan T1: perlakuan T5, perlakuan T2: perlakuan T5, perlakuan T3: perlakuan T5, dan perlakuan T4: perlakuan T5 kurang dari alpha $(\alpha=0,05)$ sehingga terdapat perbedaan yang bermakna.

\section{KESIMPULAN DAN SARAN}

Berdasarkan pada hasil yang diperoleh, dapat disimpulkan bahwa terdapat perbedaan perlakuan perbandingan sampah buah dan sayur terhadap konsumsi pakan dan indeks pengurangan sampah larva BSF. Konsumsi pakan tertinggi terdapat pada perlakuan perbandingan $80 \%$ sampah buah : 20\% sampah sayur dengan nilai $96,24 \%$. Perlakuan ini juga memiliki nilai indeks pengurangan sampah tertinggi, dengan nilai WRI sebesar 6,408 gram per hari.

Berdasarkan hasil penelitian ini diperlukan kajian lebih lanjut mengenai kandungan nutrisi pada sampah buah dan sayur terhadap pertumbuhan dan perkembangan larva BSF dalam kaitannya dengan pemanfaaatan sebagai agen biokonversi sampah organik.

\section{DAFTAR PUSTAKA}

Beesigamukama, D., Mochoge, B., Korir, N. K., K.M. Fiaboe, K., Nakimbugwe, D., Khamis, F. M., Subramanian, S., Wangu, M. M., Dubois, T., Ekesi, S., \& Tanga, C. M. (2021). Low-cost technology for recycling agro-industrial waste into nutrient-rich organic fertilizer using black soldier fly. Waste Management, 119, 183-194. https://doi.org/10.1016/j.wasman.2020.09.043 
Cammack, J. A., \& Tomberlin, J. K. (2017). The Impact of Diet Protein and Carbohydrate on Select Life-History Traits of The Black Soldier Fly Hermetia illucens (L.) (Diptera: Stratiomyidae). Insects, 8(56), 1-14. https://doi.org/10.3390/insects8020056

Enviromental Health Risk Assesment (EHRA). (2016). Laporan Studi EHRA Lumajang 2016. Lumajang: ppsp.nawasis.info

Fahmi, M. R. (2018). Maggot Pakan Ikan Protein tinggi \& Biomesin Pengolahan Sampah Organik. Jakarta: Penebar Swadaya.

Gold, M., Cassar, C. M., Zurbrügg, C., Kreuzer, M., Boulos, S., Diener, S., \& Mathys, A. (2020). Biowaste treatment with black soldier fly larvae: Increasing performance through the formulation of biowastes based on protein and carbohydrates. Waste Management, 102, 319-329. https://doi.org/10.1016/j.wasman.2019.10.036

Hakim, A. R. (2017). Studi Laju Umpan Pada Proses Biokonversi Limbah Pengolahan Tuna Menggunakan Larva Hermentia illucens. JPB Kelautan dan Perikanan , 12, 197-192

Kementrian Lingkungan Hidup dan Kehutanan. (2018). Data Pengolahan SampahKomposisi Sampah Kabupaten Lumajang. Dipetik April 6, 2020, dari Sistem Informasi Pengelolaan Sampah Nasional: http://sipsn.menlhk.go.id/?q=3akomposisi-

sampah\&field_f_wilayah_tid=1498\&field_kat_kota_tid=All\&field_periode_id_t id $=2168$

Liu, C., Wang, C., \& Yao, H. (2019). Comprehensive Resource Utilization of Waste Using the Black Soldier Fly (Hermetia illucens (L.)) (Diptera: Stratiomyidae). Animals, 9(349), 1-19.

Manurung, R., Supriatna, A., \& Esyanthi, R. R. (2016). Bioconversion of Rice straw waste by black soldier fly larvae ( Hermetia illucens L .) : Optimal feed rate for biomass production. Journal of Entomology and Zoology Studies, 4(4), 1036-1041

Meneguz, M., Schiavone, A., Gai, F., \& Dama, A. (2018). Effect of rearing substrate on growth performance, waste reduction efficiency and chemical composition of black soldier fly (Hermetia illucens) larvae. Journal of The Science of Food and Agriculture, 98(15), 5541-5932. https://doi.org/10.1002/jsfa.9127

Muhayyat, M. S. (2016). Pengaruh Jenis Limbah dan Rasio Umpan pada Biokonversi Limbah Domestik Menggunakan Larva Black Soldier Fly (Hermetia illucens). Jurnal Rekayasa Proses , 10, 23-29

Parra Paz, A. S., Carrejo, N. S., \& Gómez Rodríguez, C. H. (2015). Effects of Larval Density and Feeding Rates on the Bioconversion of Vegetable Waste Using Black 
Soldier Fly Larvae Hermetia illucens (L.), (Diptera: Stratiomyidae). Waste and Biomass Valorization, 6(6), 1059-1065. https://doi.org/10.1007/s12649-015-94188

Pusat Penelitian dan Pengembangan Permukiman. (2015). PENELITIAN PENGUKURAN KADAR AIR BUAH. Seminar Nasional Cendekiawan 2015, (hal. 12-27).

Rahmadani, E., \& Padang, P. K. K. K. (2017). Hubungan Pengetahuan, Sikap dan Ketersediaan Sarana Pengelolaan Sampah dengan Partisipasi Pedagang dalam Pengelolaan Sampah di Pasar Raya Solok Tahun 2017. 54-55

Rahmi, F. A., Yamin, M., \& Sasaerila, Y. (2020). Effect of Different Organic Wastes on the Growth of Black Soldier Fly (Hermetia illucens) Larvae. International Conference and the 10th Congress of the Entomological Society of Indonesia (ICCESI 2019), 8(Iccesi 2019), 113-116. https://doi.org/10.2991/absr.k.200513.019

Salman, N. (2020). Pengaruh dan Efektivitas Maggot Sebagai Proses Alternatif Penguraian Sampah Organik Kota di Indonesia. Serambi Engineering , 835-841

Sistem Informasi Pengelolaan Sampah Nasional, 2019. Komposisi Sampah Berdasarkan Sumber. http://sipsn.menlhk.go.id/sipsn/public/data/sumber

Wang, Y.-S., \& Shelomi, M. (2017). Review of Black Soldier Fly ( Hermetia illucens ) as Animal Feed and Human Food. Foods, 6(91), 1-23. https://doi.org/10.3390/foods6100091

Widiarti, I. W. (2012). Pengelolaan Sampah Berbasis "Zero Waste" Skala Rumah Tangga Secara Mandiri. Jurnal Sains \&Teknologi Lingkungan, 4(2), 101-113. https://doi.org/10.20885/jstl.vol4.iss2.art4 